\title{
Responsibility of Global Corporations towards Human Resource to Attain Competitive Advantage: A Review
}

\author{
Syed Hussain Haider \\ Chief Strategy Officer \\ Akhuwat, Lahore
}

\author{
Muzaffar Asad.,PhD \\ Assistant Professor \\ muzaffar.asad@ucp.edu.pk \\ School of Accounting and Finance, Faculty of Management \\ Studies, University of Central Punjab, Lahore
}

\author{
Mina Fatima \\ Institutional Development Expert, \\ P\&D Department, Government of Punjab,Lahore
}

\begin{abstract}
This article reports the responsibility of global corporations towards their human resource and activities to attain competitive advantage through creation of competitive human resource. By enhancing value to the industry in which the corporations operates, human resource can secure its place for the future. In the current era which is unpredictable the growth, deployment, and augmentation of human resource cannot be undervalued. It is difficult to mobilize and to achieve progress without essential human resource. Global corporations have to remain competitive for survival. To remain competitive corporations have to hire and retain best human resource to meet the changing economic environment and changing preferences of the customers.

Keywords: Global Corporations, Human Resource, Competitive Edge, Leadership
\end{abstract}

\section{Introduction}

The current study reports and addresses some of the major issues and patterns faced by the global corporations to remain competitive in the current era. The major issues faced by today's global corporations are scarcity of talented employees and the revamping of corporations in the current era (Vivek \& Satyanarayana Rao, 2016). The purpose of this study is to address these human resource concerns in the light of variety of literature and views of researchers regarding management of expatriate human resource, their diversity, their cultural differences, retention of employees, and attracting the best human resource in a competitive global environment to create competitive edge in the industry.

In the current era, world is altering at a rapid speed where the societal expectations of corporations are changing dramatically (Ameer \& Othman, 2012). Everyday corporations have to make important decisions related to issues of human resource and certain other countless issues that have a major influence over the ability of

The current issue and full text archive of this journal is available at www.jraspublications.org/index.php/JRAS/issue/archive

Journal of Research in Administrative Sciences

VI(II), 8-11, ISSN: 2664-2433 the global corporations for generating profit in the competitive environment. Only those corporations remain successful in the market that always looks for the smart ways to get rid of these issues (Brewster \& Sparrow, 2007). The future priorities of human resource functions are not simple, because there is not a single preference. All the factors that are contributing towards human resource functions are continuously changing with the changes in the business environment (Ameer \& Othman, 2012). For success corporations have to cater these changes and have to take all these challenges as advantages. Human resource can secure its place for the future by amalgamating with these advantages.

It is very important to understand that actively engaging employees, developing and managing talented employees, encouraging diversity and managing interactions, play an important role in enhancing the level of performance (Abebe, 2010). Above mentioned roles will not only improve the functions of human 
resource but will also enhance the productivity and performance of the organizations at large (Min \& Smyth, 2014).

The main objective of this study is to review current trends worldwide and the current practices all over the globe to understand the working of global corporations regarding management of human resources for attaining competitive advantage. This study highlights the responsibilities of these global corporations, and recommend them for reconciling these dual responsibilities and reshaping global HR practices to gain competitive edge.

The next section of the paper addresses the review of literature. Different ways will be examined that how human resource contributes to an organization to attain competitive advantage in the competitive environment. At the end recommendation will be given that how corporations can utilize their human resource in an efficient way to make them an asset that can become their competitive advantage.

\section{Literature Review}

Abridges literature has been reviewed to understand the responsibility of global corporations towards the human resource to attain competitive advantage. Corporations now a day are facing continuously changing environment which require them to change and adapt new systems for survival (Robbins, 2009). Corporations not only face consistently changing environment, but also face uncertainties and surprises, therefore, global corporations have to meet all these challenges that are created due to changing technology, re-definition of roles, trade unions, labor unions, and economic instabilities, by the effective use of human resource (Forster, 2005). All these factors are not new but the pace of change has increased tremendously. Work environment for the corporations and especially for global corporations has changed, and sometimes this change becomes confusing (Hitt, Ireland, \& Hoskisson, 2012). Due to continuously changing technology and work environment corporations have to alter their existing strategies, their product mix, and human resource strategies (Thalassinos \& Zampeta, 2012).

In this paper, the authors are addressing global corporations, and globalization here involves the integration of markets, nations, and states enabling individuals, corporations, and countries to move easily and instantly throughout the world approaching the world in a faster, deeper, and cheaper way (Thalassinos \& Zampeta, 2012). Due to change in technology, the scope of human resource has changed (Collins \& Smith, 2006). The historical dictatorship had been changed as the leaders today are equipped with latest techniques for getting better performance from the diversified human resource (Den Hartog \& Belschak, 2012). Now a day, global corporations have to respond to technological changes and have to enable new opportunities for expansion if they want to remain competitive (Burke \& Ng, 2006). All the above mentioned factors are the reason behind the dynamic environment in which businesses operate and all the issues that are implanted are due to change (Zanko, 2003). Global corporations can only cope with these challenges if they have right human resource at the right time with right knowledge and right skills and abilities (Haider, Fatima, Asad, \& Ahmad, 2016). This is possible only if global corporations succeed in creating an environment that positively contributes towards change.

There is no doubt that human resource has a key role in future in inculcating positive and beneficial organizational change for the attainment of competitive advantage (Farquharson \& Baum, 2002). If the corporations resists to change rather than changing their strategies and policies, this may hinder the growth and performance of the global corporation (Weiss \& Wilkinson, 2013). Resistance to change by the employees may retard the successful implementation of planned changes or may even result as a failure, as it encompasses behavior that terminate or retard the intended organizational change which may be for betterment or may be a need of the situation (Tse, Huang, \& Lam, 2013). The corporations, therefore, must involve their human resource while making the change process and thus, should adopt management by objective approach for the successful implementation of the change (Haider, Asad, \& Aziz, 2015). Leadership of global corporations can significantly enhance the capability of employees to accept change with a positive attitude (Abebe, 2010). If they adopt appropriate practices during the change period and show that the process is fair and they are being properly looked after then transformation and change process becomes very easy (Robbins, 2009).

Global corporations and their human resource require stability and core values, even if the environment is changing (Haider, Asad, Fatima, \& Abidin, 2017). It is the responsibility of the leadership of the global corporations to ensure the employees that they are vital for the corporation and they are valued (Tzafrir, Harel, Baruch, \& Dolan, 2004). If the leadership fails to do so then it may cause problems for the corporations like lack of trust of the employees towards organization, distress among the employees, and lack of motivation (Pinder, 2014). If the corporations focus on citizenship and ethics, corporations can become more adaptable to unstable conditions. Citizenship's performance is a set of active and voluntary behaviors. These voluntary behaviors of employee contribute positively in gaining competitive edge as employee facilitates the corporations towards the achievement of corporate goals (Wong \& Snell, 2003).

Majority of the authors do not make any difference between competitive advantage and sustained competitive advantage, but there is a variance (Macky \& Johnson, 2003). In the current study competitive advantage is taken sustained competitive advantage unless if it is specified. The sustained competitive advantage means when the competitors are unable to copy or adopt the same edge and they fail to adopt the similar strategies and practices (Coetzer, Cameron, Lewis, \& Massey, 2002). If other corporations succeed to adopt the same competitive advantage then that will no longer be a competitive advantage for the corporations as other will also be doing the same thing and may offering the same product.

Corporations can gain competitive advantage by adopting sustainable change by two main broad criteria (Asad, Sharif, \& Hafeez, 2016). First criterion is that corporations provide a continuous changing environment; they need identify on continuous basis, revitalize, upgrade, and reinvent the valuable resources of the corporation. The second criterion is that the corporation is capable of creating such an environment in which they can be selfreinforcing and enhancing in value and strength, this will make a major cost disadvantage for those corporations who would be copying the same competitive advantage that the corporation has (Crook, Ketchen, \& Snow, 2003). It is also said that creating competitive advantage through human resource is due to inability of the other resources of the corporations to create competitive advantage (Wilson, 2005).

When corporations are not capable of creating competitive advantage through other resources then they concentrate on human resource to make human resource their competitive advantage (Hatch \& Dyer, 2004). In the highly competitive economic environment characterized by such phenomena as the globalization of markets, changing customer demands, and increasing product market competition, people and the way they are managed have greater importance because other sources of attaining competitive advantage are less useful (Peacuterez, De, Falcoacuten, \& Manuel, 2002). Determination of competitive advantage through human resource is the form of resource based views (Hatch \& Dyer, 2004). According to resource based view a corporation is seen by its complex and intangible resources as compared to its activities and product lines (Peacuterez, De, Falcoacuten, \& Manuel, 2002). The advocate of resource based view claims that corporations enjoy competitive advantage because of the uniqueness of the resources that they have and the imperfect mobility of those resources (Hatch \& Dyer, 2004).

Competitive advantage because of value is provided by performance that the company receives because of investment that the company makes in hiring, training, and developing its human resource (Schuler \& Jackson, 2007). The importance of human resource arises from the fact that there are few capable people in the market 
at a time (Asad, Haider, Akhtar, \& Javaid, 2011). The limitability of imperfect human resource is provided by the level of difficulty which is associated with the duplication of employees' knowledge, employees' skills, employees' experience, and employees' behavior (Zaugg \& Thom, 2003). High cost of recruitment, selection, and training are the major reasons behind the above mentioned difficulty. Individual human nature is another major reason behind this problem.

There is no doubt in it that not everybody has the same capability for adoption to changing environment and technological changes (Beck, et al., 2014). If one is good in adopting one thing then it does not mean that the same employee may also be good in adopting the other changes. It must always be kept in mind those imperfectly imitable and sustainable employees that provide much to the competitive advantage of a corporation, rather than the human resource functions as such, due to the capability of competitors to imitate human resource policies and practices (Hailey, Elaine, \& Catherine, 2005).

\section{Implications for Global Corporations to Gain Competitive Advantage}

Globalization has arrived with information ubiquity and sensitivity As corporations compete in product and marketing, likewise, in the future corporations will compete for capable human resource that will become their asset and will prove as a mean for competitive advantage (Albrecht, Bakker, Gruman, Macey, \& Saks, 2015). The future perspective human resource will be a sensible generation and they will be energetic, highly talented who will be seeking for huge benefits and monetary rewards for luxuries that they want to enjoy in life. The future human resource will be as much loyal to the organization as the corporations will be taking care of meeting their financial requirements. Thus, corporations have to take care of the needs of the employees to keep their employees motivated. The current employees are not only interested in the corporations or their work or what they have to do for the organization but are also interested in that what the corporations are doing for them (Asad, Haider, Akhtar, \& Javaid, 2011). Despite the fact that some corporations and some countries have less tolerance for foreign managers but still due to globalization human resource managers should be prepared to hire the best human resource with best skills and talent which is the requirement of the corporation regardless of the nationality of the employee (Ramlall, 2006).

The critical components for the global leaders in the international assignments are the management of the global managers worldwide and to get best out of them (Brewster \& Sparrow, 2007). According to global approach the corporations should hire best human resource regardless of the geographical boundaries, hiring local people for local business is a multinational approach and not a global approach. Keeping a balance and maintaining an effective global human resource without conflicts is a major challenge for the global corporations (Haider, Fatima, Asad, \& Ahmad, 2016). Leadership of global corporations should use different and flexible strategies for the management of global human resource to attain competitive advantage out of the human resource.

It has been observed that Y generation employees like flexible work hours, as they want to enjoy their time according to their desires, where as baby boomers want freedom to work part time, as many want to retire early but still want to hang on to their healthcare and other benefits (Coetzer, Cameron, Lewis, \& Massey, 2002). Therefore, leaders of global corporations have to build such a framework that may allow flexibility to develop and manage all different workforce options.

The leadership of global corporations has to plan for outsourced suppliers, fulltime, part-time, and temporary employees in a global business environment that may entail diverse, highly talented, and skilled people. Another very important thing that the leadership has to think is that they have to develop their employees in such a way that they may prove as an asset for the corporation in future (Crook, Ketchen, \& Snow, 2003). By having such a talented, skilled, and dedicated human resource corporations can build a sustainable competitive advantage (Asad, Haider, Akhtar, \& Javaid, 2011).
There is a need of horizontal collaboration between business units as a network and personal between individuals in a team. There is also a need of vertical collaboration between leadership and employees (Hitt, Ireland, \& Hoskisson, 2012).

\section{Conclusions}

In the light of the literature reviewed and the discussion that has been made, it is concluded that in the coming era the human resource managers have to develop positive employment relations. This development of positive and successful relations will build interpersonal relationships as well as will help to improve productivity and hence the overall performance of the organization. There is no one best solution for all the global corporations, the global corporations must develop flexible systems depending on the environment in which they are operating.

According to resource based views the value rareness imperfect sustainability of human resource of an organization were shown to provide the means for an organization to attain an advantage over their competitors. Competitive advantage, because of human resource can be achieved by a variety of human resource strategies being implemented within the organization. These strategies include recruitment, selection promotion and development of the human resource. The diagram mentioned in the paper shows the strategies that the corporations can follow in the global corporations. The method mentioned in the paper is one of the areas that the leadership of global corporations have to concentrate to fulfill the needs of employees from baby boomers as well as y generation employees. In short the role of global human resource is to provide sustained competitive advantage through recognizing and achieving many different ideas and perspectives into the management of the human resource functions. Similarly, if human resource is properly developed, managed, and sustained, then it can be an integral part of making competitive advantage. The value of human resource can also be achieved through attentive and forward thinking management. Furthermore, organizational productivity can be enhanced through competitive advantage by the human resource.

\section{Recommendations}

From the perspective of leadership of global corporations there are multiple implications like skill development and knowledge acquisition for the management of expatriates in a global corporation. These implications are necessary to manage the human resource that belongs to diverse culture and religious background. The leaders of global corporations need to develop the skills and abilities that are required to compete on a global scale. Corporations are depending more and more on their leadership to create, and sustain a competitive human resource to attain competitive advantage (Coetzer, Cameron, Lewis, \& Massey, 2002).

Global corporations need to align human resource processes to remain competitive and successful in the market (Robbins, 2009). Global corporations have to develop flexible human resource systems that may cater the diverse human resource with different cultures, values, and attitudes. Individuals seek values and attitudes when they share their selves with diverse human resource of different traditions and cultural backgrounds.

\section{References}

i. Abebe, M. A. (2010). Top team composition and corporate turnaround under environmental stability and turbulence. Leadership \& Organization Development Journal, 31(3), 196 $-212$.

ii. Albrecht, S. L., Bakker, A. B., Gruman, J. A., Macey, W. H., \& Saks, A. M. (2015). Employee engagement, human resource management practices and competitive advantage: An integrated approach. Journal of Organizational Effectiveness: People and Performance, 2(1), 7-35. doi:10.1108/JOEPP-082014-0042 
iii. Ameer, R., \& Othman, R. (2012). Sustainability practices and corporate financial performance: A study based on the top global corporations. Journal of Business Ethics, 108(1), 61-79. doi:10.1007/s10551-011-1063-y

iv. Asad, M., Haider, S. H., Akhtar, M. B., \& Javaid, M. U. (2011). Human Resource Practices and Enterprise Performance in Small and Medium Enterprises of Pakistan. First International Conference on Contemporary Issues of Business (pp. 1-18). Lahore: Comsats.

v. Asad, M., Sharif, M. N., \& Hafeez, M. (2016). Moderating effect of network ties on the relationship between entrepreneurial orientation, market orientation, and performance of MSEs. Paradigms A Research Journal of Commerce, Economics, and Social Sciences, 10(2), 74-81.

vi. Beck, S., Borie, M., Chilvers, J., Esguerra, A., Heubach, K., Hulme, M., . . . Gör. (2014). Towards a reflexive turn in the governance of global environmental expertise. The cases of the IPCC and the IPBES. GAIA-Ecological Perspectives for Science and Society, 80-87.

vii. Brewster, C., \& Sparrow, P. (2007). People Management. Advances in. Technology Inspire a Fresh Approach to International HRM. International Review of Business Research.

viii. Burke, R. J., \& Ng, E. (2006). The changing nature of work and organizations: Implications for human resource management. Human Resource Management Review, 16(2), 86-94. doi:10.1016/j.hrmr.2006.03.006

ix. Coetzer, A., Cameron, A., Lewis, K., \& Massey, C. (2002). Human resource management practices in selected Neww Zealand small and medium-sized enterprises. International Journal of Organisational Behaviour.

x. Collins, C. J., \& Smith, K. G. (2006). Knowledge exchange and combination: The role of human resource practices in the performance of high-technology firms. Academy of Management Journal, 49(3), 544-560. doi:10.5465/AMJ.2006.21794671

xi. Crook, T. R., Ketchen, D. J., \& Snow, C. C. (2003). Competitive edge: A strategic management model. Cornell Hotel and Restaurant Administration Quarterly.

xii. Den Hartog, D. N., \& Belschak, F. D. (2012). When does transformational leadership enhance employee proactive behavior? The role of autonomy and role breadth selfefficacy. Journal of Applied Psychology, 97(1), 194-202. doi:10.1037/a0024903

xiii. Farquharson, L., \& Baum, T. (2002). Enacting organisational change programmes: a centre stage role for HRM? International Journal of Contemporary Hospitality Management.

xiv. Forster, N. (2005). Maximum performance: a practical guide to leading and managing people at work. New York: Edward Elgar Publishing.

xv. Haider, S. H., Asad, M., \& Aziz, A. (2015). A survey on the determinants of entrepreneurial training effectiveness among micro finance institutions of Malaysia. Mediterranean Journal of Social Sciences, 6(6 S4), 396-403. doi:10.5901/mjss.2015.v6n6s4p396

xvi. Haider, S. H., Asad, M., Fatima, M., \& Abidin, R. Z. (2017). Microfinance and performance of micro and small enterprises: Does training have an impact. Journal of Entrepreneurship and Business Innovation, 4(1), 1-13. doi:https://doi.org/10.5296/jebi.v4i1.10566

xvii. Haider, S. H., Fatima, M., Asad, M., \& Ahmad, A. Z. (2016). A study on the issue of employment contracts and practices of employmen contracts in UAE. Paradigms A Journal of Commerce, Economics, and Social Sciences, 10(1), 58-64.

xviii. Hailey, H., Elaine, V. F., \& Catherine, T. (2005). The HR department's role in organisational performance. Human Resource Management Journal. xix. Hatch, N. W., \& Dyer, J. H. (2004). Human capital and learning as a source of sustainable competitive advantage. Strategic Management Journal.

xx. Hitt, M., Ireland, R. D., \& Hoskisson, R. (2012). Strategic Management Cases: Competitiveness and Globalization. New York: Cengage Learning.

xxi. Huselid, M. A. (1995). The impact of human resource management practices on turnover, productivity, and corporate financial performance. Academy of Management Journal, 38(3), 635-672. doi:10.2307/256741

xxii. Losey, M., Ulrich, D., \& Meisinger, S. (2005). The Future of Human Resource Management: 64 Thought Leaders Explore the Critical HR Issues of Today and Tomorrow. New York: Wiley Publishers.

xxiii. Macky, K., \& Johnson, G. (2003). Managing Human Resources in New Zealand. Chicago: McGraw Hill.

xxiv. Min, B. S., \& Smyth, R. (2014). Corporate governance, globalization and firm productivity. Journal of World Business, 49(3), 372-385. doi:10.1016/j.jwb.2013.07.004

xxv. Peacuterez, S., De, P., Falcoacuten, G., \& Manuel, J. (2002). A resource-based view of human resource management and organizational capabilities development. The International Journal of Human Resource Management.

xxvi. Pinder, C. C. (2014). Work Motivation in Organizational Behavior, Second Edition. New York: Psychology Press.

xxvii. Ramlall, S. J. (2006). Identifying and understanding HR competencies and their relationship to organizational practices. Applied H.R.M. Research.

xxviii. Robbins, S. P. (2009). Essentials of Organizational Behavior. Chicago: Prentice Hall.

xxix. Schuler, R. S., \& Jackson, S. E. (2007). Strategic human resource management. Chicago: Wiley-Blackwell.

xxx. Thalassinos, I. E., \& Zampeta, V. (2012). How corporate governance and globalization affect the administrative structure of the shipping industry. Journal of Global Business and Technology, 8(1), 48-52.

xxxi. Tse, H. H., Huang, X., \& Lam, W. (2013). Why does transformational leadership matter for employee turnover? A multi-foci social exchange perspective. The Leadership Quarterly, 24(5), 763-776. doi:10.1016/j.leaqua.2013.07.005

xxxii. Tzafrir, S. S., Harel, T. 1., Baruch, Y., \& Dolan, S. L. (2004). The consequences of emerging HRM practices for employees' trust in their managers. Personnel Review.

xxxiii. Vivek, S., \& Satyanarayana Rao, A. V. (2016). A study on employee retention in private sector banks. The Journal of Indian Management, 6(2), 82-89.

xxxiv. Weiss, T. G., \& Wilkinson, R. (2013). Rethinking global governance? Complexity, authority, power, change. International Studies Quarterly, 58(1), 207-215. doi:10.1111/isqu.12082

xxxv. Wilson, J. P. (2005). Human resource development: learning \& training for individuals \& organizations. Bradford: Kogan Page Publishers.

xxxvi. Wong, D., \& Snell, D. L. (2003). Employee workplace effectiveness: Implications for performance management practices and research. Journal of General Management.

xxxvii. Zanko, M. (2003). Change and Diversity: HRM Issues and Trends in the Asia-Pacific Region. Asian Pacific Journal of Human Resource.

xxxviii. Zaugg, R., \& Thom, N. (2003). Excellence through implicit competencies: Human resource management - organisational development - knowledge creation. Journal of Change Management. 